\title{
Protein separation performance of self-assembled block copolymer membranes $\uparrow$
}

\begin{abstract}
J. Hahn, ${ }^{a}$ J. I. Clodt, ${ }^{* a}$ V. Filiz ${ }^{a}$ and V. Abetz ${ }^{a b}$
A comprehensive study of the separation performance of highly porous self-assembled integral asymmetric block copolymer membranes was carried out. Four different polystyrene- $b$-poly(4-vinylpyridine) (PS- $b$ P4VP) diblock copolymers were used to prepare membranes with pore sizes increasing with the molecular weight of the polymers. The pore sizes vary from $17 \mathrm{~nm}$ to $53 \mathrm{~nm}$. Clean water fluxes and the adsorption of lysozyme, myoglobin, haemoglobin, catalase and ferritin on the membranes were studied. Diffusion rates of the proteins were examined and selectivities are discussed. The membranes show promising results regarding the separation of different proteins in the range of around four to twelve $\mathrm{nm}$. The characteristics of PS- $b$-P4VP diblock copolymer membranes were compared with a commercially available polycarbonate track-etched membrane.
\end{abstract}

Received 4th December 2013 Accepted 16th January 2014

DOI: $10.1039 / \mathrm{c} 3 \mathrm{ra} 47306 \mathrm{f}$

www.rsc.org/advances
Due to the huge potential of nanoporous materials with uniform pore sizes, several studies were performed to develop improved membrane structures, to figure out and to understand their separation performance, especially for proteins. ${ }^{15-17}$ In this context the passive diffusion of proteins through membranes is a versatile method for protein separation or longterm release, since the avoidance of physical or chemical stresses protects against denaturing of the proteins. ${ }^{3}$

The combination of self-assembly of amphiphilic block copolymers (S) and the non-solvent induced phase separation process (NIPS) allows preparing integral-asymmetric membranes with highly ordered, hexagonally arranged pores in a fast onestep process. ${ }^{18}$ These membranes show a thin selective layer on top consisting of hexagonally arranged cylinders merging in a sponge-like substructure underneath. Polystyrene-block-poly(4vinylpyridin) (PS- $b$-P4VP) was the first block copolymer used to prepare the desired membrane structures and is therefore wellexamined regarding its membrane formation. In the last years a lot of progress was achieved in membranes fabrication using SNIPS (a combination of self-assembly and the non-solvent induced phase separation process) including e.g. the expansion on various di- and triblock copolymer systems, ${ }^{19-23}$ the investigation of the influence of additives, ${ }^{24-26}$ and of the structure formation process. ${ }^{27-29}$ This proves a high adaptability of the sensitive and fascinating process and its resulting membrane structures leading to a further increase of their range of application. Our recent results show that the pore sizes of PS- $b$-P4VP membranes are tunable in the range of $20 \mathrm{~nm}$ to $70 \mathrm{~nm} .{ }^{30}$ The pores of the membranes mainly downsize by decreasing the molecular weights of PS- $b$-P4VP used for the corresponding membrane casting solutions. The potential of isoporous PS- $b$ P4VP membranes for the separation of biomolecules was pointed out previously in diffusion experiments using membranes with
${ }^{a}$ Helmholtz-Zentrum Geesthacht, Institute of Polymer Research Max-Planck-Str.1, 21502 Geesthacht, Germany. E-mail: juliana.clodt@hzg.de; Fax: +49 4152 872499; Tel: +494152872472

${ }^{b}$ University of Hamburg, Institute of Physical Chemistry, Grindelallee 117, 20146 Hamburg, Germany

$\dagger$ Electronic supplementary information (ESI) available. See DOI: $10.1039 / \mathrm{c} 3 \mathrm{ra} 47306 \mathrm{f}$ 
pore sizes of $34 \mathrm{~nm} .{ }^{31}$ Bovine serum albumin (BSA) and globulin$\gamma(\operatorname{IgG})$ could be effectively separated. Furthermore the membrane allowed the selective separation of similarly sized proteins based on charge effects, as stated for the separation of BSA and bovine hemoglobin. After quaternization of the membrane it was possible to separate these proteins effectively by varying the $\mathrm{pH}$ due to their different isoelectric points.

Self-assembled PS- $b$-P4VP membranes under investigation with pore sizes of several tens of nanometers combine a sharp pore size distribution, high porosity and their production is easily up-scalable. This is an ideal basis for an excellent separation performance, in particular with respect to commercially available isoporous polymeric membranes. To the best of our knowledge up to now no comprehensive investigation of the performance of PS- $b$-P4VP membranes and the influence of various pore sizes was carried out. In this work we are looking in detail on the clean water flux over $40 \mathrm{~h}$, the adsorption of proteins and the separation selectivity of PS- $b$-P4VP membranes with various pore sizes between five model proteins in diffusion experiments.

\section{Experimental}

\section{PS- $b$-P4VP diblock copolymers}

Tetrahydrofuran (THF) was ordered from Th. Geyer. Styrene and 4-vinylpyridine (4VP) were ordered from Sigma-Aldrich and purified as per description. THF was purified by successive distillation from potassium under purified argon atmosphere. Styrene was stirred with dibutylmagnesium $\left(\mathrm{MgBu}_{2}\right) .4 \mathrm{VP}$ was distilled once under reduced pressure from calcium hydride $\left(\mathrm{CaH}_{2}\right)$ and twice from ethylaluminium dichloride. PS- $b$-P4VP was synthesized via sequential anionic polymerization at $-67^{\circ} \mathrm{C}$ in THF. The polymerization of styrene was initiated with secbutyl lithium (sec-BuLi). After $4 \mathrm{~h}, 4 \mathrm{VP}$ was added and the solution was stirred for another $16 \mathrm{~h}$. The polymerization was quenched with degassed methanol. After partial removal of THF under reduced pressure, the polymer was precipitated in water. The composition of the block copolymer was determined by ${ }^{1} \mathrm{H}$-NMR spectroscopy. All ${ }^{1} \mathrm{H}-\mathrm{NMR}$ measurements were performed on a Bruker Advance 300 NMR spectrometer at $300 \mathrm{MHz}$ with internal standard [tetramethylsilane (TMS)] using chloroform $\left(\mathrm{CDCl}_{3}\right)$ as a solvent. Molecular weights of the PS precursors and polydispersities were determined by gel permeation chromatography (GPC). The number averaged molecular weights of the block copolymers were calculated from the number averaged molecular weight of the PS precursor obtained by GPC and the composition obtained by ${ }^{1} \mathrm{H}-\mathrm{NMR}$. GPC measurements were performed at $50{ }^{\circ} \mathrm{C}$ in dimethylacetamide (DMAC) using $3 \mu$ PSS SDV gel columns at a flow rate of $1.0 \mathrm{~mL}$ $\min ^{-1}$ (VWR-Hitachi 2130 pump). A Waters 2410 refractive-index $\operatorname{detector}(\lambda=930 \mathrm{~nm})$ and a PS calibration curve were used.

\section{Protein solutions}

Lysozyme (Lys) from chicken egg white, myoglobin (Myo) from equine skeletal muscle, haemoglobin (Hem) from bovine blood, catalase (Cat) from bovine liver and ferritin (Fer) from equine spleen were purchased from Sigma Aldrich. Sodium chloride, potassium dihydrogenphosphate and disodium hydrogenphosphate dodecahydrate used for phosphate buffered saline (PBS) solutions were purchased from Sigma Aldrich. Protein concentrations were determined using the UV-Vis spectrophotometer Genesys $10 \mathrm{~S}$ (Thermo Scientific) at a wave length of $280 \mathrm{~nm}$ and $409 \mathrm{~nm}$, respectively.

\section{Membranes used in this work}

The isoporous diblock copolymer membranes used in this work were prepared according to a procedure recently published by Rangou et $a l^{30}$ Therefore PS- $b$-P4VP diblock copolymers synthesized as described above were dissolved in a solvent mixture of THF and DMF. The solutions were cast on a polyester nonwoven support using a casting machine. The films were left for a certain time on air before immersing them in water. The membranes were dried at $60{ }^{\circ} \mathrm{C}$ under reduced pressure before use.

The commercial polycarbonate track-etched membranes (PC30) used in this work were purchased from Pieper Filter $\mathrm{GmbH}$, supplier number PCN3CP04700, pore sizes $30 \mathrm{~nm}$, porosity $\sim 0.4$ as stated by supplier.

Scanning electron microscopy (SEM) of the membranes was carried out on a LEO Gemini $1550 \mathrm{VP}$ at a voltage of $3 \mathrm{kV}$ or $5 \mathrm{kV}$. The samples were coated with $2.0 \mathrm{~nm}$ platinum. The crosssections of the membranes were dipped in iso-propanol, frozen in liquid nitrogen and cracked. Average pore size values were determined using the software analySIS (Olympus) on basis of the SEM results. Image 1.46 (Wayne Rasband, National Institute of Health, USA) was used to determine the porosity of our membranes.

\section{Water-flux experiments}

Water flux measurements were performed in dead-end mode using a home-made automatic testing device at transmembrane pressures of 2.0 bar to 2.3 bar at room temperature. The volume was measured gravimetrically every 15 and $30 \mathrm{~min}$ for $40 \mathrm{~h}$, respectively. The actual pressure was recorded as well. The effective membrane area was $1.77 \mathrm{~cm}^{2}$. These studies were conducted employing demineralized water with an electrical conductivity of $\approx 0.055 \mu \mathrm{S} \mathrm{cm}{ }^{-1}$.

\section{Adsorption experiments}

Adsorption experiments adjusted to a known procedure ${ }^{32}$ were carried out with five different proteins of different hydrodynamic diameters and isoelectric points: values for hydrodynamic diameters $\left(D_{\mathrm{h}}\right)$ and isoelectric points (IEP) as stated by supplier; Lys $\left(D_{\mathrm{h}}=3.8 \mathrm{~nm}\right.$, IEP $\left.=11.4\right)$, Myo $\left(D_{\mathrm{h}}=4.4 \mathrm{~nm}, \mathrm{IEP}=\right.$ $7.2)$, Hem $\left(D_{\mathrm{h}}=6.4 \mathrm{~nm}\right.$, IEP $\left.=7.1\right)$, Cat $\left(D_{\mathrm{h}}=10.2 \mathrm{~nm}\right.$, IEP $=$ 5.4) and Fer $\left(D_{\mathrm{h}}=12.0 \mathrm{~nm}, \mathrm{IEP}=7.2\right) .2 \mathrm{~mL}$ of a $1 \mathrm{~g} \mathrm{~L}^{-1}$ solution of the proteins in PBS buffer solution (10 mM PBS, $9 \mathrm{wt} \%$ of $\mathrm{NaCl}$ in demineralized water) at different $\mathrm{pH}$ were placed on a membrane disc of $2 \mathrm{~cm}$ in diameter in a small closed vial. The vials were shaken at $90 \mathrm{rpm}$ for $24 \mathrm{~h}$ at $25^{\circ} \mathrm{C}$ to reach equilibrium. The membranes were rinsed two times with $2 \mathrm{~mL}$ of the PBS buffer solution for 10 minutes. The protein adsorption on the membrane was calculated as follows: 
Protein adsorbed $=\frac{m(\text { ads }, \text { protein })}{\text { membrane area }}=\frac{m_{0}-\left(m_{2}+m_{\mathrm{w} 2}+m_{\mathrm{w} 2}\right)}{A}$, where $m_{0}$ is the mass of the protein in the solution before the adsorption experiment, $m_{1}$ is the mass of the protein in solution after the adsorption experiment and $m_{\mathrm{w} 1}$ and $m_{\mathrm{w} 2}$ are the masses of the protein in the washing solutions and $A$ is the membrane area. The concentration of the protein solution where measured by UV as stated before.

\section{Diffusion experiments}

A side-by-side diffusion cell (PermeGear) was used to study the diffusion of five model proteins through our membranes. The system consists of two chambers with $6 \mathrm{~mL}$ volumes, namely the donor (right chamber) and the receptor compartment (left chamber). The orifice diameter allows an accessible membrane area of $2.04 \times 10^{-4} \mathrm{~m}^{2}$ (effective diameter: $16.1 \mathrm{~mm}$ ). Each chamber is equipped with a magnetic stirrer to allow continuous mixing and avoid concentration gradients in the chamber itself. The effect of stirring speed on the diffusion through the membrane was studied at $100 \mathrm{rpm}, 200 \mathrm{rpm}$, and $300 \mathrm{rpm}$. Otherwise the stirring speed was kept constant to $100 \mathrm{rpm}$. The system is constantly heated to $37^{\circ} \mathrm{C}$. PBS with low ionic strength of $10 \mathrm{mM}$ and a pH of 5.4, 7.4 and 11.8, respectively, was used as diffusion medium. The buffer was prepared using $\mathrm{Na}_{2} \mathrm{HPO}_{4} \times$ $12 \mathrm{H}_{2} \mathrm{O}, \mathrm{KH}_{2} \mathrm{PO}_{4}, \mathrm{NaCl}$, and Millipore water. The $\mathrm{pH}$ was adjusted by adapting the proportions between the salts or by adding $\mathrm{NaOH}$, respectively. The buffer was used within five days after preparation.

Initially the membrane is placed between the two chambers exposing the ordered surface structure towards the donor chamber. The system is tightly sealed using a cell clamp. Both chambers are filled with $6 \mathrm{~mL}$ of the diffusion medium at least 16 hours before the diffusion experiment is started. This enables a good wetting and swelling of the membranes. To start the experiments both cells are emptied. The receptor cell is filled again with $6 \mathrm{~mL}$ PBS, while the donor cell is filled with $6 \mathrm{~mL}$ protein solution $(0.5,1.0$, and $2.0 \mathrm{mg}$ protein per $\mathrm{mL}$ PBS of the respective $\mathrm{pH})$. Samples of the receptor medium were taken after $15 \mathrm{~min}, 1 \mathrm{~h}, 2 \mathrm{~h}, 4 \mathrm{~h}, 6 \mathrm{~h}, 8 \mathrm{~h}, 24 \mathrm{~h}, 26 \mathrm{~h}, 28 \mathrm{~h}$, and $30 \mathrm{~h}$. Therefore the solution in the receptor cell was completely removed and refilled with fresh PBS. After $24 \mathrm{~h}$ the receptor compartment was rinsed once with PBS buffer to remove residual proteins. After $30 \mathrm{~h}$ the solution in the donor compartment was removed for further analysis. Each diffusion measurement was performed at least three times.

Protein concentrations were determined by UV within one hour after sample collection. The flux $J$ of the proteins through the membrane can be calculated based on the law of Fickian diffusion. Therefore the permeability coefficient can be obtained from the slope of the diffusant concentration $C$ versus time $t(1 \mathrm{~h}$ to $24 \mathrm{~h}) .{ }^{33}$ The error bars drawn in the diagram correspond to the maximum deviation from the mean value

$$
P=\frac{\Delta m}{\Delta t} /\left(A C_{0}\right) \quad \frac{\Delta m}{\Delta t}=\frac{\Delta c}{\Delta t} 0.006 L
$$

$A$ : membrane surface area $C_{0}$ : concentration at $t=0 \mathrm{~s}$.
The effective diffusion coefficient $D_{\text {eff }}$ of proteins was calculated according to Lu et al. ${ }^{34-36}$ and allows determining the theoretically separation selectivity $S$ based on our single protein diffusion experiments

$$
D_{\text {eff }}=P l \quad S=\frac{D_{\text {eff }}(\text { protein a })}{D_{\text {eff }}(\text { protein } \mathrm{b})}
$$

$l$ : thickness of the membrane.

\section{Results and discussion}

\section{Membranes used in this work}

In order to obtain membranes with different pore sizes four different PS- $b$-P4VP diblock copolymers were used in this work. Therefore the previous published procedure ${ }^{37}$ was adjusted to develop membranes with pore sizes smaller than $20 \mathrm{~nm}$. The molecular characteristics of the polymers and resulting geometrical feature of the membranes are listed in Table 1 in which the numbering of the membranes is according to their pore sizes. Fig. 1 depicts SEM image of the surfaces and crosssections of the membranes.

\section{Clean water-flux experiments}

Clean water fluxes were measured over 40 hours for four different PS- $b$-P4VP diblock copolymer membranes (M17, M23, M34, and M53) and one commercially available polycarbonate track-etched membrane (PC30). The results are shown in Fig. 2.

As expected the fluxes increase with the pore size of the PS- $b$ P4VP membranes. The flux declines over $40 \mathrm{~h}$ were calculated and are listed in Table 2. For M17, M23 and M34 the water flux values are quite stable throughout the measurement leading to small flux declines below 30\%. The negative flux decline value for M17 could be caused by some small polymer particles inside the raw membrane which are pressed out during the measurement leading to an increased flux after some time. Another explanation is that the deviance of the water flux values is bigger for M17 since the values are quite small leading to a higher relative error during the measurement. The flux decline increases with the pore size of the PS- $b$-P4VP block copolymer membranes.

Interestingly the flux decline is much higher for M53 than for the other membranes. The initial flux of this membrane was $1465 \mathrm{~L} \mathrm{~m}^{-2} \mathrm{~h}^{-1} \mathrm{bar}^{-1}$. After $40 \mathrm{~h}$ it seems to approximate a stable state with a flux value of around $400 \mathrm{~L} \mathrm{~m}^{-2} \mathrm{~h}^{-1} \mathrm{bar}^{-1}$. The huge flux decline of M53 could be caused by an increased swelling of the $\mathrm{P} 4 \mathrm{VP}$ chains that are in this case quite longer $\left(\sim 50 \mathrm{~kg} \mathrm{~mol}^{-1}\right)$ compared to the other membranes (M34 $30 \mathrm{~kg} \mathrm{~mol}^{-1}, \mathrm{M} 23$ $\sim 18 \mathrm{~kg} \mathrm{~mol}^{-1}$, and M17 $\sim 13 \mathrm{~kg} \mathrm{~mol}^{-1}$ ). Furthermore it has to be mentioned that the water fluxes over $40 \mathrm{~h}$ for M34 and M53 could not be measured continuously since our measurement set up can only measure up to a limit of $4 \mathrm{~L}$ water. The water fluxes for M34 and M53 are so high that the overall volume of water is more than $4 \mathrm{~L}$ leading to interval measurements. During the measurement breaks the membranes are kept wet in the system over night. Therefore the higher flux declines for M34 and M53 could also be generated by an increased fouling on the surface 
Table 1 PS-b-P4VP diblock copolymers and commercial polycarbonate track-etched membrane used in this work, resulting pore diameter, porosity, thickness, and numbering of the membranes

\begin{tabular}{|c|c|c|c|c|c|c|c|}
\hline PS- $b$-P4VP & $\begin{array}{l}M_{\mathrm{n}} \\
{\left[\mathrm{kg} \mathrm{mol}^{-1}\right]}\end{array}$ & $\begin{array}{l}\text { PS } \\
{[\mathrm{wt} \%]}\end{array}$ & $\begin{array}{l}\text { P4VP } \\
{[\mathrm{wt} \%]}\end{array}$ & $\begin{array}{l}\text { Pore } \\
\text { diameter }^{a}[\mathrm{~nm}]\end{array}$ & $\begin{array}{l}\text { Average } \\
\text { porosity [\%] }\end{array}$ & $\begin{array}{l}\text { Average } \\
\text { membrane } \\
\text { thickness }[\mu \mathrm{m}]\end{array}$ & $\begin{array}{l}\text { Membrane } \\
\text { numbering }\end{array}$ \\
\hline $\mathrm{PS}_{83} \mathrm{P}_{4 \mathrm{VP}_{17}}{ }^{76}$ & 76 & 83 & 17 & $17 \pm 2$ & 13.6 & 68 & M17 \\
\hline $\mathrm{PS}_{83.7} \mathrm{P} \mathrm{VP}_{16.3}{ }^{113}$ & 113 & 83.7 & 16.3 & $23 \pm 2$ & 18.7 & 56 & M23 \\
\hline $\mathrm{PS}_{81} \mathrm{P}_{4} \mathrm{VP}_{19} 160$ & 160 & 81 & 19 & $34 \pm 4$ & 25.8 & 48 & M34 \\
\hline $\mathrm{PS}_{80} \mathrm{P}_{4 \mathrm{VP}_{20}}{ }^{252}$ & 252 & 80 & 20 & $53 \pm 5$ & 31.5 & 44 & M53 \\
\hline \multicolumn{4}{|c|}{ Commercial polycarbonate track-etched membrane } & 30 & 0.4 & 7 & PC30 \\
\hline
\end{tabular}

${ }^{a}$ The numeric value is attributed to the average pore size followed by the \pm standard deviation.

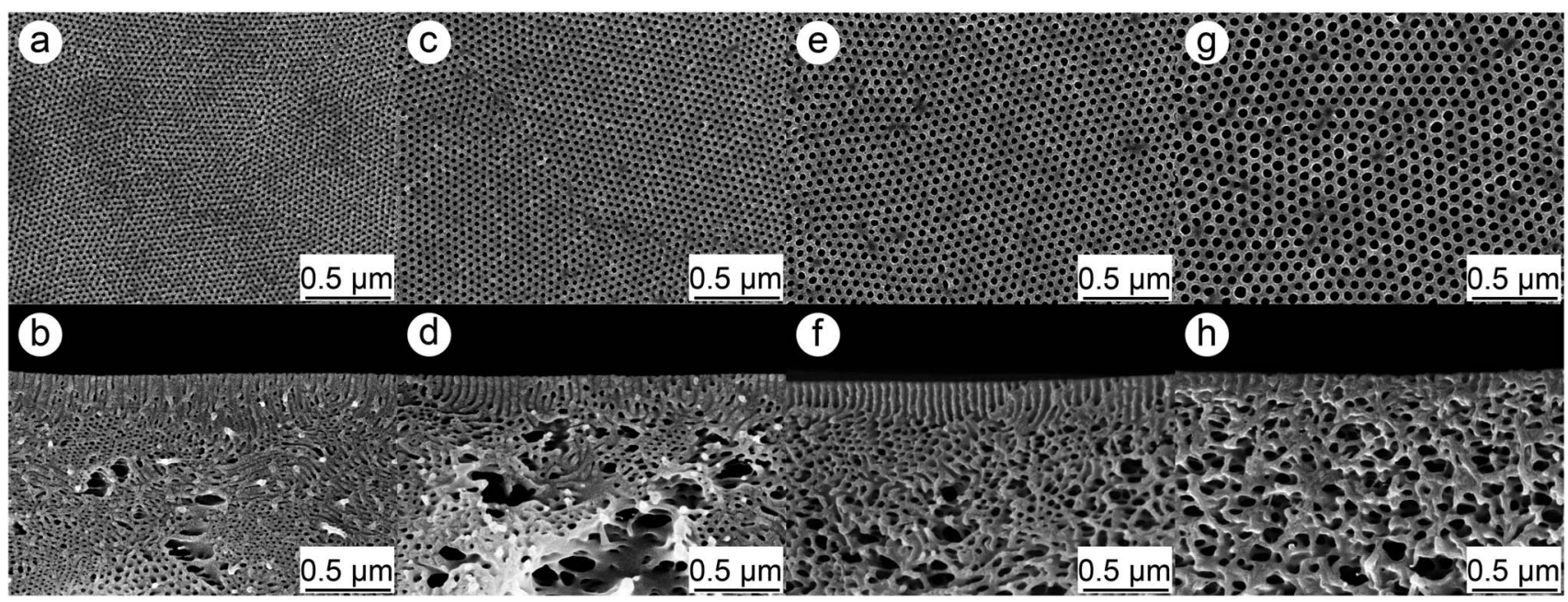

Fig. 1 SEM pictures of the surfaces and cross-section of membranes M17 made from $\mathrm{PS}_{83} \mathrm{P} 4 \mathrm{VP} \mathrm{P}_{17}{ }^{76}$ (a and b), M23 from $\mathrm{PS} \mathrm{S}_{83.7} \mathrm{P} 4 \mathrm{VP} \mathrm{P}_{16.3^{113}}$ (c and d), M34 from $\mathrm{PS}_{81} \mathrm{P} \mathrm{VPP}_{19}{ }^{160}$ (e and f), and M53 from $\mathrm{PS}_{80} \mathrm{P} \mathrm{VP}_{20}{ }^{252}$ ( $\mathrm{g}$ and $\mathrm{h}$ ).

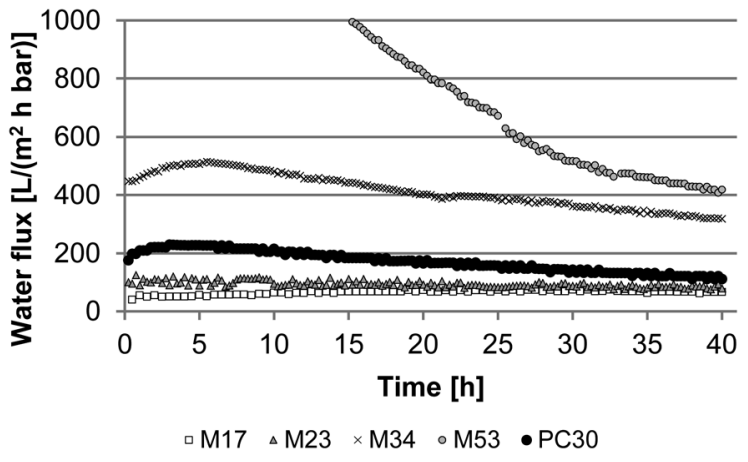

Fig. 2 Water flux measurements for membranes made from M17, M23, M34, M53, and PC30.

Table 2 Water flux values and flux decline for PS- $b$-P4VP membranes

\begin{tabular}{lclc}
\hline Membrane & $\begin{array}{l}\text { Initial flux } \\
{\left[\mathrm{L} \mathrm{m}^{-2} \mathrm{~h}^{-1} \mathrm{bar}^{-1}\right]}\end{array}$ & $\begin{array}{l}\text { Flux after } 40 \mathrm{~h} \\
{\left[\mathrm{~L} \mathrm{~m}^{-2} \mathrm{~h}^{-1} \mathrm{bar}^{-1}\right]}\end{array}$ & $\begin{array}{l}\text { Flux } \\
\text { decline [\%] }\end{array}$ \\
\hline M17 & & 67 & -22 \\
M23 & 55 & 90 & 11 \\
M34 & 101 & 321 & 25 \\
M53 & 1465 & 418 & 72 \\
PC30 & 198 & 111 & 44
\end{tabular}

due to the longer times the membranes are kept in water. An increased amount of bacteria was observed for M34 to M53 after flux measurements as shown in Fig. S1.†

\section{Adsorption experiments}

A detailed analysis of the adsorption of different proteins on isoporous diblock copolymer membranes was necessary for this study. On the one hand adsorption of proteins on membranes is correlated to their fouling behavior which is important when it comes to application. On the other hand the adsorption of proteins on the membrane surface and substructure reduces the effective pore diameters and further lead to partial or full pore blocking. ${ }^{35}$ The adsorption was tested both at physiological $\mathrm{pH} 7.4$ and at the IEP of the proteins. The latter one is important because the adsorption can be different when the overall charge of the proteins are neutral (at IEP), positive $(\mathrm{pH}<$ IEP) or negative $(\mathrm{pH}>$ IEP) due to electrostatic interaction with the membrane surface. For Myo, Hem and Fer the IEP is close to $\mathrm{pH}$ 7.4. Therefore no additional measurements were carried out. The results of the adsorption measurements are depicted in Fig. 3 and 4.

At $\mathrm{pH} 7.4$ the amount of adsorption of Lys, Myo, Hem, and Cat concerning the different membranes M23, M34, and M53 is independent of the membrane pore size and polymer used for 


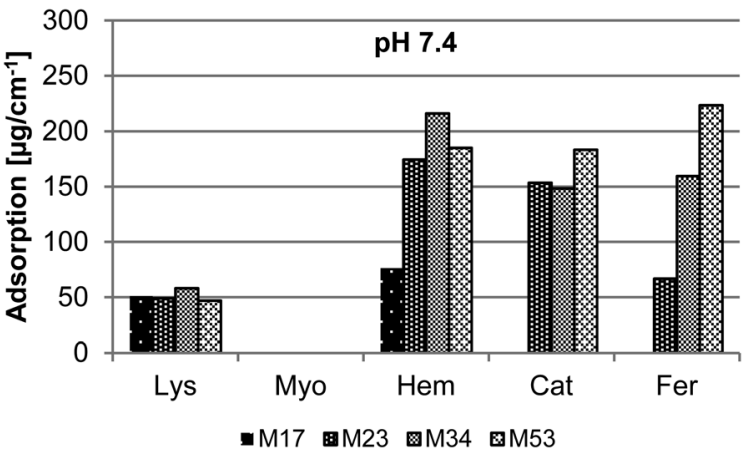

Fig. 3 Adsorption of Lys, Myo, Hem, Cat, and Fer in PBS buffered solution ( $\mathrm{pH}$ 7.4) on isoporous diblock copolymer membranes M17, M23, M34, and M53.

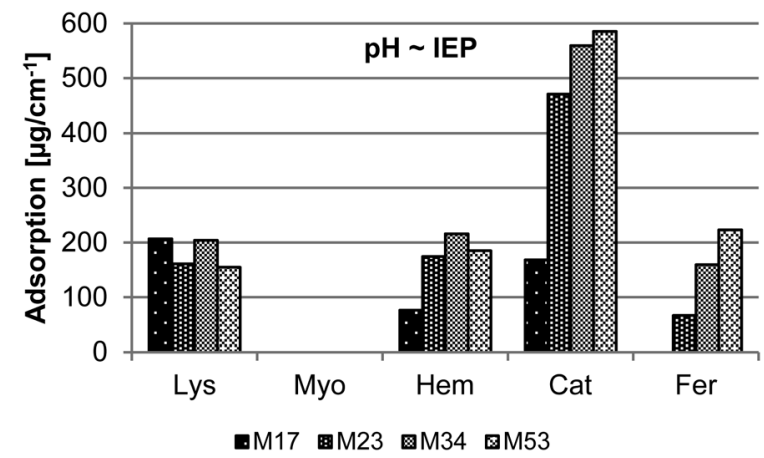

Fig. 4 Adsorption of Lys, Myo, Hem, Cat, and Fer in PBS buffered solution ( $\mathrm{pH} \sim$ isoelectric point of the protein) on isoporous diblock copolymer membranes M17, M23, M34, and M53.

the membrane formation, respectively. Small deviation in the absorption value may be caused by the error of the method and UV system included. Interestingly Myo is the only protein without any measurable adsorption on the membrane surface. In contrast to the other proteins the adsorption of Fer increases with the molecular weight of the polymer, respectively the pore size of the membrane. For the biggest proteins, Fer and Cat, no adsorption was observed at $\mathrm{pH} 7.4$ on M17. In this case the effective pore diameters are too small for the proteins to allow any or huge amounts of proteins to reach the substructure of the membrane and adsorb there. Also for Hem the adsorption is considerably lower on the membrane with the smallest pore size M17 corresponding to the results observed for Cat and Fer.

At $\mathrm{pH} \sim \mathrm{IEP}$ the adsorption has the same tendency as for $\mathrm{pH}$ 7.4 when the different membranes are compared. For Lys and Cat (compare also Fig. S2 $\dagger$ ) the adsorption is much higher at neutral state (IEP) than at $\mathrm{pH}$ 7.4, although Lys is positively and Cat negatively charged at $\mathrm{pH}$ 7.4. The repulsive interaction between the proteins themselves seems to be too high to let the proteins attach to the membrane surface. In case of Cat an adsorption even for the membrane with the smallest pores M17 was observed, but the value of adsorption is still much lower than for the other membranes.
For the commercial track-etched membrane PC30 the adsorption was tested as well. Here it was not possible to detect any adsorption with our method. The supplier specifies a very low adsorption for these types of membranes which is in accordance with our measurements. Compared to PS- $b$-P4VP membranes, track-etched membranes do not have a spongy substructure and differ considerably in the chemical structure. On the one hand, their decreased adsorption could be due to the smaller overall surface of the polymer just as the smaller thickness of PC30 compared to our membranes. On the other hand, we assume that their functional surface groups allow less attractive interactions between the membrane and the proteins.

\section{Diffusion experiments}

In order to investigate the separation performance of our membranes, diffusion experiments with proteins were carried out. Therefore we will provide a closer look on the effect of the pore size.

Besides the characteristics of the membrane, the protein and their interaction, the diffusion of proteins is affected by various measuring parameters. Some of them will be discussed as follows.

First, the ionic strength significantly affects the electrostatic double layer thickness (Debye length) of proteins and membrane surface areas. Previous studies carried out that an ionic strength of $10 \mathrm{mM}$ allows combining high separation selectivity and high flux using PS- $b$-P4VP membranes and proteins with a hydrodynamic diameter of about $6.8 \mathrm{~nm}$. These conditions lead to a Debye length of about $3.3 \mathrm{~nm}$ still having a significant impact especially when small protein and pore sizes are considered. ${ }^{31}$

In the following the influence of the stirring speed and the initial concentration in the donor chamber will be examined. In these studies Myo was used as a model protein, since it does not show any adsorption to PS- $b$-P4VP membranes. Size selective separation by diffusion of different proteins will be discussed for M17, M23, M34, M53 including the influence of $\mathrm{pH}$ and pore sizes. Furthermore the results are compared with the performance of the commercial membrane PC30.

\section{Influence of stirring speed}

The mass transport by diffusion through membranes is hindered by a developing laminar boundary layer influencing the diffusion coefficient $D_{\text {eff. }}$ The additional resistance on the surface of the membranes and further concentration gradients in the receptor chamber can be minimized due to a sufficient mixing. The influence of the stirring speed on the mass transport was determined. Therefore the stirring speed in diffusion experiments using M53 and $1 \mathrm{mg} \mathrm{mL}^{-1}$ Myo was varied between $100 \mathrm{rpm}, 200 \mathrm{rpm}$, and $300 \mathrm{rpm}$. Further parameters were kept constant. The results depicted in Table 3 show, that the diffusion coefficient is slightly increasing with rising stirring speed. This effect can be attributed to the reduction of the laminar boundary layer on the surface of the membrane. For each speed step itself the difference is within the range of error. As 
Table 3 Permeability coefficients $P$ and diffusion coefficients $D_{\text {eff }}$ of Myo in PBS (pH 7.4) through M53 using different stirring speeds or initial donor protein concentrations at $37^{\circ} \mathrm{C}$

\begin{tabular}{llllll}
\hline Stirring speed $[\mathrm{rpm}]$ & $P\left[10^{-6} \mathrm{~cm} \mathrm{~s}^{-1}\right]$ & $D_{\text {eff }}\left[10^{-9} \mathrm{~cm}^{2} \mathrm{~s}^{-1}\right]$ & Conc. Myo $\left[\mathrm{mg} \mathrm{mL}^{-1}\right]$ & $P\left[10^{-6} \mathrm{~cm} \mathrm{~s}^{-1}\right]$ & $D_{\text {eff }}\left[10^{-9} \mathrm{~cm}^{2} \mathrm{~s}^{-1}\right]$ \\
\hline 100 & 67.4 & 296.7 & 0.5 & 73.4 & 322.8 \\
200 & 74.7 & 328.7 & 1.0 & 67.4 & 71.6
\end{tabular}

expected, the diffusion profiles provided in the ESI Fig. S3 show that the diffusion rate increases. For our purpose we assumed a stirring speed of $100 \mathrm{rpm}$ to be sufficient since above $100 \mathrm{rpm}$ the stirrers in our measuring device became more and more unstable increasing the risk of membrane damage.

\section{Influence of initial protein concentration}

The concentration of the protein in the receptor chamber can significantly influence the mass transport. Since Myo is several times smaller than the pore size of M53 concentration dependent Fickian diffusion is expected. The influence of the initial protein concentration on the diffusion profile of Myo through M53 is presented in the ESI Fig. S4. $\dagger$ The concentration of Myo was varied between $0.5 \mathrm{mg} \mathrm{L}^{-1}, 1.0 \mathrm{mg} \mathrm{L}^{-1}$, and $2.0 \mathrm{mg} \mathrm{L}^{-1}$. The curves show that the cumulative amount of diffusant is directly proportional to the initial concentration of the protein. Thus, the diffusion coefficient $D_{\text {eff }}$ for all concentrations is nearly the same (Table 3). For further experiments we chose an initial concentration of $1 \mathrm{mg} \mathrm{mL}^{-1}$ protein in the donor compartment.

\section{Size selective separation by diffusion}

The diffusion of five model proteins, namely Lys, Myo, Hem, Cat, and Fer through PS- $b$-P4VP membranes with different pore sizes was investigated. These proteins have been chosen to determine the size selective separation performance of our membranes using proteins with mainly globular shape. The proteins are further characterized e.g. by different isoelectric points (IEP), functional groups, and hydrophilic-to-hydrophobic ratio leading to a variety of possible interactions between the membrane surface area and each protein.

Since the membranes are supported by a nonwoven, the impact of the support on the diffusion rate of each model protein was carried out. Diffusion profiles and selectivities of the non-woven are provided in the ESI Fig. S5 and Table S1. $\dagger$ This study proved that the nonwoven itself does not have a significant selectivity towards the proteins. Furthermore the mass transport is very irregular based on the huge mesh sizes of the support and its inhomogeneity. Nevertheless the nonwoven acts as an additional barrier limiting the free diffusion of proteins due to its thickness.

\section{Influence of $\mathrm{pH}$ of the release medium}

The $\mathrm{pH}$ of the release medium is one parameter significantly effecting the interaction and the size of the nanopore and the protein. In order to gain a first insight in the effect of $\mathrm{pH}$, the diffusion through M53 was measured under physiological conditions (pH 7.4) and at $\mathrm{pH} \sim$ IEP of the protein. As depicted in Fig. 5, Lys and Myo show the highest diffusion rate through the membrane M53 attributed to their small hydrodynamic radii. Their mass transport is quite similar at $\mathrm{pH}$ 7.4. In general bigger-sized proteins provide a significantly slower diffusion through the membrane. Fer, as the biggest protein, has the lowest diffusion rate. However, under this conditions, Cat diffuses faster through the membrane than Hem. We assume this to be based on the higher hydrophilicity of Cat compared to Hem. Since the pore walls of our membranes are hydrophilic (P4VP), Cat meets less resistance leading to an increased diffusion compared to Hem.

The isoelectric point of Myo, Hem, and Fer is almost present under physiological conditions. Therefore the results of the measurement at pH 7.4 can be used. Contrary the IEP of Lys and Cat is found at 11.4 or 5.4, respectively. The diffusion measurements performed at the IEP of these proteins show a decrease in the diffusion rate for both of them (Fig. 6).

This can be attributed to an increased adsorption of the proteins on the membrane, which was carried out in the adsorption studies. This adsorption can induce a lag time in diffusion, as we found for Lys (see ESI Fig S6†). Using a preadsorbed membrane, a membrane after adsorption testing, leads to the absence of the lag time. Here the diffusion is nearly comparable to the results at $\mathrm{pH} 7.4$ over the first $8 \mathrm{~h}$ of the measurement. However, afterwards the diffusion slows down. Previous studies showed that the diffusion of Lys is slower near to its IEP compared to low $\mathrm{pH}$ conditions. ${ }^{12}$ This is assumed to be based on the missing repulsion of the Lys molecules due to their nearly absent charge at their IEP. Lys exists as monomers or dimers at low $\mathrm{pH}$. On the contrary the protein can assemble to oligomers at a $\mathrm{pH}$ close to its IEP. ${ }^{38}$ Therefore the effective size of the protein is bigger leading to slower diffusion. M53 has a very big pore size compared to the size of Lys of $3.8 \mathrm{~nm}$. Therefore we presume, that the adsorption does not affect the pore size in the initial steps of the measurement of M53 to an extend that an additional resistance for the diffusion of Lys arises.

However, Cat shows a slower diffusion throughout the measurement. We suggest that the high adsorption of Cat at its IEP leads to the reduction of the effective pore size of the membrane and pore blocking. This is supported by SEM analysis of the membrane structure after adsorption testing (Fig. S2 $\dagger$ ).

\section{Influence of pore size}

The diffusion profiles of the five model proteins at physiological $\mathrm{pH}$ using the membranes M17, M23, and M34 are depicted in the ESI Fig. S7 $\dagger$ and their diffusion coefficients and separation 


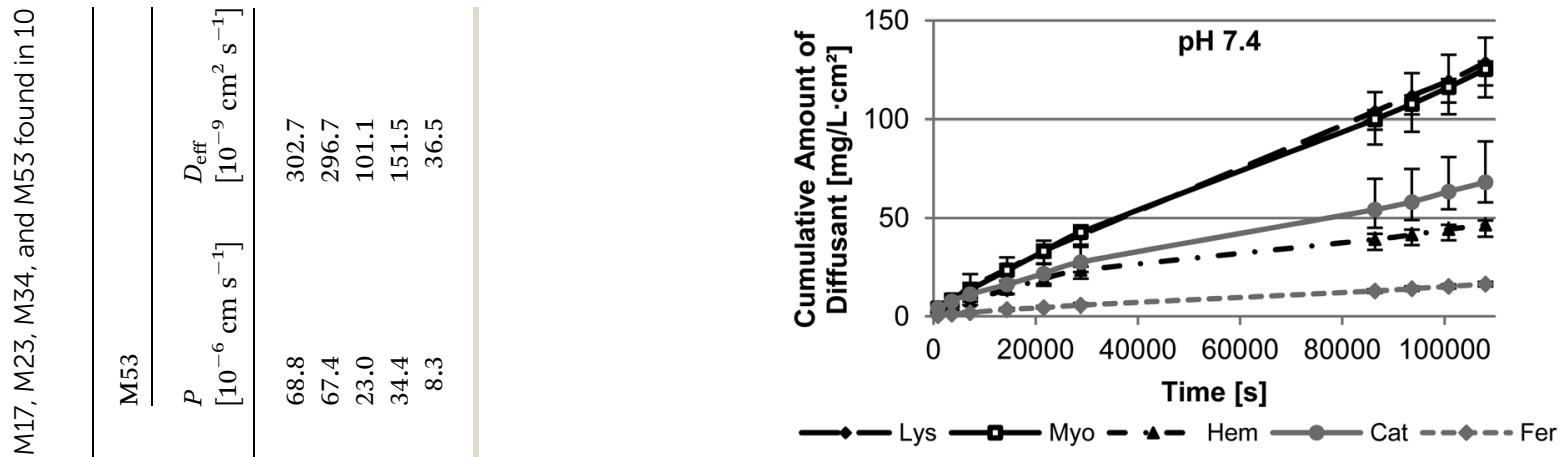

Fig. 5 Diffusion profiles showing the cumulative amount of diffusant in the receptor chamber over time of the five proteins Lys, Myo, Hem, Cat, and Fer $\left(1 \mathrm{mg} \mathrm{mL}^{-1}\right)$ through $\mathrm{M} 53$ at pH 7.4, $37^{\circ} \mathrm{C}$ and $100 \mathrm{rpm}$.

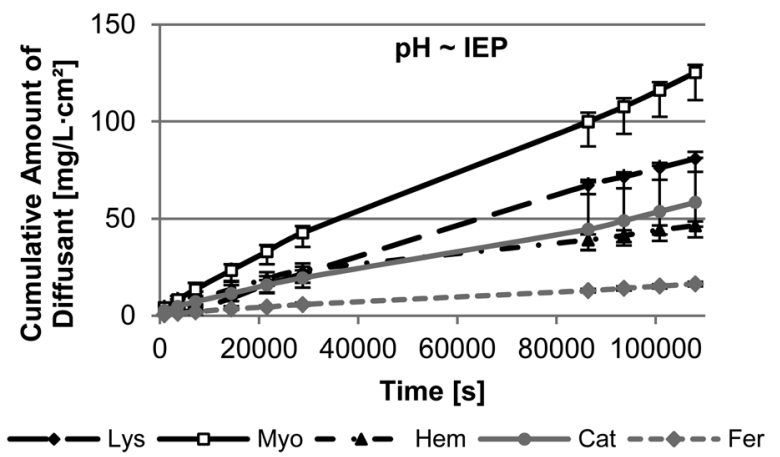

Fig. 6 Diffusion profiles showing the cumulative amount of diffusant in the receptor chamber over time of the five proteins Lys, Myo, Hem, Cat, and Fer $\left(1 \mathrm{mg} \mathrm{mL}^{-1}\right)$ through $\mathrm{M} 53$ at $\mathrm{pH} \sim \mathrm{IEP}, 37^{\circ} \mathrm{C}$ and $100 \mathrm{rpm}$.

selectivities are listed in Tables 4 and 5 . Based on these results we figure out the influence of pore size on the diffusion rate of the proteins and the separation selectivity.

The order of the model protein mass transports through M17, M23, and M34 is similar to those of M53.

While a reduction of the pore size from M53 to M34 is in accordance with a decrease of the diffusion constant $D_{\text {eff }}$ for the big-sized proteins Cat and Fer, the diffusion of Lys, Myo, and

Table 5 Separation selectivities of PS- $b$-P4VP membranes calculated by dividing the diffusion coefficients $D_{\text {eff }} a / D_{\text {eff }} b$ of the proteins determined in single diffusion experiments

\begin{tabular}{|c|c|c|c|c|c|c|}
\hline \multicolumn{2}{|c|}{ Protein a/protein $b$} & \multirow{2}{*}{$\begin{array}{r}\text { M17 } \\
0.8\end{array}$} & \multirow{2}{*}{$\begin{array}{r}\text { M23 } \\
1.0\end{array}$} & \multirow{2}{*}{$\begin{array}{r}\text { M34 } \\
1.1\end{array}$} & \multirow{2}{*}{$\frac{\text { M53 }}{1.0}$} & \multirow[t]{2}{*}{ PC3C } \\
\hline Lys & Myo & & & & & \\
\hline & Hem & 3.7 & 4.3 & 3.2 & 3.0 & \\
\hline & Cat & 2.8 & 2.9 & 2.6 & 2.0 & \\
\hline & Fer & 8.7 & 27.3 & 11.5 & 8.3 & \\
\hline \multirow[t]{3}{*}{ Myo } & Hem & 4.7 & 4.3 & 2.8 & 2.9 & \\
\hline & Cat & 3.6 & 2.9 & 2.4 & 2.0 & 1.9 \\
\hline & Fer & 11.0 & 27.4 & 10.3 & 8.1 & 6.8 \\
\hline \multirow[t]{2}{*}{ Hem } & Cat & 0.8 & 0.7 & 0.8 & 2.8 & \\
\hline & Fer & 2.3 & 6.4 & 3.6 & 2.8 & \\
\hline Cat & Fer & 3.1 & 9.3 & 4.4 & 4.2 & 3.6 \\
\hline
\end{tabular}


Hem is not affected. The diffusion of proteins in narrow nanopores is effected by a variety of parameters and differs markedly from their free diffusion. A nanopore size of $34 \mathrm{~nm}$ to $53 \mathrm{~nm}$ is large in scale compared to protein sizes of $3 \mathrm{~nm}$ to $7 \mathrm{~nm}$ of Lys, Myo, and Hem. As a result the hydrodynamic hindrance for small proteins is not increasing due to interactions between the protein and the pore. This correlates well with our assumption of the mass transport of Lys through M53 at different $\mathrm{pH}$. When pore size and protein size converge, their interaction and electrostatic repulsion increase leading to a decreasing diffusion speed. In the range of pore size this behaviour is found for proteins with outer diameter of $10 \mathrm{~nm}$ to $12 \mathrm{~nm}$. These proteins experience a retaining force although the pore size is more than twice as large as the hydrodynamic diameter being in accordance with previous work. ${ }^{16,31}$ On the one hand the adsorption of proteins reduces the effective pore size as discussed in the analysis of the adsorption measurements. On the other hand electrostatic repulsion, protein structure and process parameters influence the effective size of the protein, the nanopore and their interactions. For M23 a reduction of the diffusion coefficient of all model proteins is found. This effect continues when using M17. In these cases the mass transport is also strongly reduced for small proteins. On the one hand the size of nanopore and small proteins become close leading to increasing interactions and their diffusion slows down. Our results and the restriction of the diffusion of the proteins can be directly linked to the adsorption of the proteins discussed before. On the other hand the surface porosity of the membranes is decreasing from M53 to M17. Therefore the effective diffusion area for the proteins decreases as well, leading to lower mass transport rates.

Table 5 shows the separation selectivities $S$ of the investigated membranes, that are mainly increasing with decreasing pore size of the PS- $b$-P4VP membrane until it reaches a maximum of 27 for the separation of Myo or Lys and Fer at a pore size of $23 \mathrm{~nm}$. In addition good selectivities for the separation of Hem/Fer and Cat/Fer could be found.

\section{Comparison with commercial track-etched membrane PC30}

The performance of our membranes is compared to PC30. The membrane was tested in diffusion experiments using Myo, Cat, and Fer.

In comparison PS- $b$-P4VP membranes with similar pore sizes, M23 and M34, provide significantly higher separation selectivities between Myo/Fer and Cat/Fer. However, their permeability coefficients are lower compared to PC30. This can be attributed to an at least six times larger thickness of PS- $b$ P4VP membranes compared to PC30. Furthermore an additional resistance arises due to the thickness of the nonwoven support, resulting in a loss of permeability, as already discussed. However, taking into account the thickness of the block copolymer membrane layer the diffusion coefficient $D_{\text {eff }}$ of small proteins through PS- $b$-P4VP membranes is considerably higher than for PC30. This applies to the entire range of pore sizes and can be attributed to the high porosity of our membranes.

\section{Conclusions}

In this work we investigated the protein separation performance of self-assembled amphiphilic diblock copolymer membranes. Four PS- $b$-P4VP membranes varying in pore size from $17 \mathrm{~nm}$ to $53 \mathrm{~nm}$ were studied concerning clean water fluxes, adsorption and passive diffusion of five proteins. The results were compared with one commercially available polycarbonate tracketched membrane.

The water fluxes increase with the pore sizes of the PS- $b$-P4VP membranes while the flux decline increases as well presumable caused by a higher fouling.

The adsorption of proteins on PS- $b$-P4VP membranes was influenced by pore size, $\mathrm{pH}$ of the media and type of protein. Our results confirm the impact of the interaction of proteins and membranes regarding effective pore sizes and performance. The study provided a detailed basis for both our diffusion experiments and further examination of the membrane characteristics.

For diffusion experiments initial process parameters like stirring speed and the donor concentration were set. Size selective separation by single diffusion of different proteins show that the diffusion coefficient and selectivities for our membranes are significantly higher compared to the polycarbonate membrane. Overall the PS- $b$-P4VP membrane with pore diameter of $23 \mathrm{~nm}$ shows the best theoretical selectivity between myoglobin and ferritin. The difference in diffusion rates indicates a possible effective separation of proteins with only $2 \mathrm{~nm}$ difference in size.

Further improvement of the protein separation and membrane flux could be obtained using post-modified PS- $b$ P4VP membranes. This can be attributed to selective protein pore interactions or decreasing protein adsorption leading to antifouling behaviour. Dual stimuli responsive isoporous membranes as described before ${ }^{37}$ could enable temperature switchable diffusion of biomolecules and therefore bear a high potential in medical application. The performance of PS- $b$-P4VP membranes could be improved by reduction of the membrane thickness or increase of the porosity of the substructure.

When it comes to application mixed protein solutions should be studied regarding their adsorption and diffusion behaviour as well.

\section{Acknowledgements}

The authors thank Brigitte Lademann for the synthesis of the polymers, Kristian Buhr for the preparation of the membranes, Sofia Rangou for scientific discussion, Barbara Bajer for the help with the adsorption and diffusion measurements, Maren Brinkmann for the GPC measurements, Silvio Neumann for the NMR and Jan Pohlmann for construction of the automatic water flux set-up. This work is financially supported by FP7 EU-project SELFMEM under grant agreement NMP3-SL-2009-228652.

\section{Notes and references}

1 A. Saxena, B. P. Tripathi, M. Kumar and V. K. Shahi, Adv. Colloid Interface Sci., 2009, 145, 1-22. 
2 R. van Reis and A. Zydney, Curr. Opin. Biotechnol., 2001, 12, 208-211.

3 G. Jeon, S. Y. Yang and J. K. Kim, J. Mater. Chem., 2012, 22, 14814.

4 G. M. Geise, H.-S. Lee, D. J. Miller, B. D. Freeman, J. E. McGrath and D. R. Paul, J. Polym. Sci., Part B: Polym. Phys., 2010, 48, 1685-1718.

5 N. Savage and M. Diallo, J. Nanopart. Res., 2005, 7, 331342.

6 B. Van Der Bruggen, C. Vandecasteele, T. Van Gestel, W. Doyen and R. Leysen, Environ. Prog., 2003, 22, 46-56.

7 S. Y. Yang, I. Ryu, H. Y. Kim, J. K. Kim, S. K. Jang and T. P. Russell, Adv. Mater., 2006, 18, 709-712.

8 B. B. Lakshmi and C. R. Martin, Nature, 1997, 388, 758-760. 9 P. Stroeve and N. Ileri, Trends Biotechnol., 2011, 29, 259-266. 10 W. M. Clark, A. Bansal, M. Sontakke and Y. H. Ma, J. Membr. Sci., 1991, 55, 21-38.

11 W. S. Dai and T. A. Barbari, Biomaterials, 2000, 21, 13631371.

12 C. Mattisson, P. Roger, B. Jönsson, A. Axelsson and G. Zacchi, J. Chromatogr. B: Biomed. Sci. Appl., 2000, 743, 151-167.

13 B. C. Robertson and A. L. Zydney, J. Colloid Interface Sci., 1990, 134, 563-575.

14 P. van Rijn, M. Tutus, C. Kathrein, L. Zhu, M. Wessling, U. Schwaneberg and A. Boker, Chem. Soc. Rev., 2013, 42, 6578-6592.

15 N. Ileri, R. Faller, A. Palazoglu, S. E. Letant, J. W. Tringe and P. Stroeve, Phys. Chem. Chem. Phys., 2013, 15, 965-971.

16 C. C. Striemer, T. R. Gaborski, J. L. McGrath and P. M. Fauchet, Nature, 2007, 445, 749-753.

17 S. Y. Yang, J. A. Yang, E. S. Kim, G. Jeon, E. J. Oh, K. Y. Choi, S. K. Hahn and J. K. Kim, ACS Nano, 2010, 4, 3817-3822.

18 K. V. Peinemann, V. Abetz and P. F. Simon, Nat. Mater., 2007, 6, 992-996.

19 R. M. Dorin, W. A. Phillip, H. Sai, J. Werner, M. Elimelech and U. Wiesner, Polymer, 2014, 1, 347-353.

20 J. Hahn, V. Filiz, S. Rangou, J. Clodt, A. Jung, K. Buhr, C. Abetz and V. Abetz, J. Polym. Sci., Part B: Polym. Phys., 2013, 51, 281-290.

21 J. Hahn, V. Filiz, S. Rangou, B. Lademann, K. Buhr, J. I. Clodt, A. Jung, C. Abetz and V. Abetz, Macromol. Mater. Eng., 2013, 298, 1315-1321.
22 A. Jung, V. Filiz, S. Rangou, K. Buhr, P. Merten, J. Hahn, J. Clodt, C. Abetz and V. Abetz, Macromol. Rapid Commun., 2013, 34, 610-615.

23 A. Jung, S. Rangou, C. Abetz, V. Filiz and V. Abetz, Macromol. Mater. Eng., 2012, 297, 790-798.

24 M. Gallei, S. Rangou, V. Filiz, K. Buhr, S. Bolmer, C. Abetz and V. Abetz, Macromol. Chem. Phys., 2013, 214, 1037-1046.

25 J. I. Clodt, S. Rangou, A. Schroder, K. Buhr, J. Hahn, A. Jung, V. Filiz and V. Abetz, Macromol. Rapid Commun., 2013, 34, 190-194.

26 P. Madhavan, K. V. Peinemann and S. P. Nunes, ACS Appl. Mater. Interfaces, 2013, 5, 7152-7159.

27 L. Oss-Ronen, J. Schmidt, V. Abetz, A. Radulescu, Y. Cohen and Y. Talmon, Macromolecules, 2012, 45, 9631-9642.

28 D. S. Marques, U. Vainio, N. M. Chaparro, V. M. Calo, A. R. Bezahd, J. W. Pitera, K.-V. Peinemann and S. P. Nunes, Soft Matter, 2013, 9, 5557.

29 R. M. Dorin, D. S. Marques, H. Sai, U. Vainio, W. A. Phillip, K.-V. Peinemann, S. P. Nunes and U. Wiesner, ACS Macro Lett., 2012, 1, 614-617.

30 S. Rangou, K. Buhr, V. Filiz, J. I. Clodt, B. Lademann, J. Hahn, A. Jung and V. Abetz, J. Membr. Sci., 2014, 451, 266-275.

31 X. Qiu, H. Yu, M. Karunakaran, N. Pradeep, S. P. Nunes and K. V. Peinemann, ACS Nano, 2013, 7, 768-776.

32 A. Jayalakshmi, S. Rajesh and D. Mohan, Appl. Surf. Sci., 2012, 258, 9770-9781.

33 B. Steffansen, B. Brodin and C. U. Nielsen, in Molecular Biopharmaceutics: Aspects of Drug Characterisation, Drug Delivery and Dosage Form Evaluation, ed. B. Steffansen, B. Brodin and C. U. Nielsen, Pharmaceutical Press, London, Chicago, 1st edn, 2009, ch. 3.2, pp. 135-152.

34 C. H. Lu and W. J. Lin, J. Biomed. Mater. Res., 2002, 63, 220225.

35 Y. S. Polyakov and A. L. Zydney, J. Membr. Sci., 2013, 434, 106-120.

36 S. Yamane, K. Takayama and T. Nagai, J. Controlled Release, 1998, 50, 103-109.

37 J. I. Clodt, V. Filiz, S. Rangou, K. Buhr, C. Abetz, D. Hoche, J. Hahn, A. Jung and V. Abetz, Adv. Funct. Mater., 2013, 23, 731-738.

38 F. Carlsson, M. Malmsten and P. Linse, J. Phys. Chem. B, 2001, 105, 12189-12195. 